\title{
Familial generalized lentiginosis
}

INSERM

\section{Source}

INSERM. (1999). Orphanet: an online rare disease and orphan drug data base. Familial generalized lentiginosis. ORPHA:231040

Familial generalized lentiginosis is a rare, inherited, skin hyperpig mentation disorder characterized by widespread lentigines without associated noncutaneous abnormalities. Patients present multiple brown to dark brown, non-elevated macula of 0.2 to $1 \mathrm{~cm}$ in diameter, spread over the entire body, sometimes including palms or soles, but never oral mucosa. 